\title{
Effect of Dolomitic Lime on Production of Asci and Pseudothecia of Venturia inaequalis and V. pirina
}

\author{
R. A. Spotts, L. A. Cervantes, and F. J. A. Niederholzer, Oregon State University, Mid-Columbia Agricultural \\ Research and Extension Center, Hood River 97031
}

\begin{abstract}
Spotts, R. A., Cervantes, L. A., and Niederholzer, F. J. A. 1997. Effect of dolomitic lime on production of asci and pseudothecia of Venturia inaequalis and V. pirina. Plant Dis. 81:96-98.

An autumn application of dolomitic lime to infected leaves on the orchard floor resulted in a decrease in the percentage of apple and pear leaves with pseudothecia, the number of pseudothecia per leaf, and the number of asci per pseudothecium of Venturia inaequalis and V. pirina. A dolomitic lime application of 5.08 metric tons per hectare reduced the ascospore dose the following spring up to $88 \%$ for pear and $92 \%$ for apple.
\end{abstract}

Apple scab, caused by Venturia inaequalis (Cooke) G. Wint., and pear scab, caused by $V$. pirina Aderhold, are present in all apple- and pear-growing districts in Oregon. An important practice for managing apple scab in an integrated program is reduction of primary inoculum. Several nonchemical sanitation procedures are effective and include shredding of leaves (18) and application in the fall of nitrogenous fertilizers such as urea $(3,10)$. Only one report describes the effect of lime on $V$. inaequalis (15). In that study, an autumn application of lime caused a reduction in the number of ascospores discharged the following spring, but urea was more effective than lime. No research has been published on the effect of lime on V. pirina.

In the spring of 1993, weather was favorable for scab in the Hood River Valley, and seven moderate or high scab infection periods occurred during April and May. In addition, over $14 \%$ leaf scab occurred the previous year in the research orchard at the Mid-Columbia Agricultural Research and Extension Center (MCAREC). Despite favorable spring weather and a high primary inoculum potential, leaf scab infection in unsprayed apple and pear trees was less than 3\% (R. A. Spotts, unpublished data). The only practice that was done differently from previous years was an appli-

Corresponding author: R. A. Spotts

E-mail: spottsro@ccmail.orst.edu

Use of trade names in this article does not imply endorsement by Oregon State University of the products named or criticism of similar products not mentioned. Oregon Agricultural Experiment Station Technical Paper 11036.

Accepted for publication 7 October 1996.

Publication no. D-1996-1028-06R

(C) 1997 The American Phytopathological Society cation of dolomitic lime at 5.08 metric tons per hectare to all research orchards on 19 October 1992.

The purpose of this study was to determine the effect of an autumn application of dolomitic lime on $V$. inaequalis and $V$. pirina in scab-infected leaves on the orchard floor during the following spring. The study was conducted for two seasons with one rate of dolomitic lime for apple leaves and three rates for pear leaves.

\section{MATERIALS AND METHODS}

Pear (Pyrus communis L.) leaves with scab lesions were collected from trees in a commercial orchard in the lower Hood River Valley at early leaf drop on 21 October 1993 (cv. d'Anjou) and 21 October 1994 (cv. Bosc). Apple (Malus pumila (L.) Mill. 'Golden Delicious') leaves with scab lesions were collected on 21 October 1993 and 24 October 1994. On the day of collection, leaves were placed between two layers of nylon mesh and placed in the herbicide strip on the orchard floor at MCAREC, Hood River. Prior to the positioning of the upper mesh cover, dolomitic lime (National Mineral Products, Salinas, CA) containing 22.7 and $11.8 \%$ of elemental calcium and magnesium, respectively, was applied evenly over the surface of the leaves with a flour sifter. Rates of dolomitic lime of 1.27 and 2.54 metric tons per hectare were applied to pear leaves and 5.08 metric tons per hectare to pear and apple leaves. Control leaves of apple and pear received no lime. One group of apple or pear leaves covering about $0.35 \mathrm{~m}^{2}$ was treated with each lime concentration. The six plots were spaced along a $10-\mathrm{m}$ linear distance of the herbicide strip.

Five to 10 leaves were removed at biweekly intervals from bud swell in midMarch through mid-June 1994 and from late February to early June 1995. Ascospore development was assessed in five pseudothecia per leaf with the differential count method of Gadoury and MacHardy, in which asci are classified as immature, mature, or empty (8), and the number of asci per pseudothecium was determined. The number of pseudothecia per leaf was determined with a dissecting microscope at $\times 12.5$, and the mean of the biweekly observations was calculated.

On 24 April, 10 and 24 May, and 7 June 1995 for pear and 9 and 23 May and 6 June 1995 for apple, the area of each leaf or leaf piece evaluated for production of asci and pseudothecia was determined with an area meter (model LI-3000, LiCor, Inc., Lincoln, NE). The averages of the leaf area values were calculated and used in $t$ test (apple) or regression (pear) analyses.

\section{RESULTS}

As the concentration of dolomitic lime applied to leaves increased, the percentage of leaves with pseudothecia, the number of pseudothecia per leaf, and the number of asci per pseudothecium decreased. This effect was observed in both pear (Table 1) and apple (Table 2) leaves in 1994 and 1995. For pear, four of the six regressions of averages of biweekly pseudothecial data on lime concentration were significant $(P=0.05$; Table 1). Similarly, the effects of dolomitic lime on pseudothecia in apple leaves were significant $(P=0.01$; Table 2$)$.

Based on the percentage of leaves with pseudothecia, the number of pseudothecia per leaf, and the number of asci per pseudothecium, the ascospore dose of each lime treatment was calculated and compared with the nonlimed control. Ascospore dose was reduced 46 to $88 \%$ for pear and 55 to $92 \%$ for apple (Table 3). The effects of dolomitic lime on ascospore dose appeared greater in 1994 than in 1995. Within 1 week after the autumn, 1994, dolomitic lime application, $22 \mathrm{~cm}$ of rain fell and removed much of the visible lime deposit from the leaf surfaces, possibly reducing the effect of the lime the following spring. Application of dolomitic lime also resulted in reductions in leaf area of 11 , 29 , and $34 \%$ for pear with $1.27,2.54$, and 5.08 metric tons of lime per hectare, respectively, and the regression of leaf area on lime concentration was significant at $P$ $=0.05$ (Table 3). For apple, lime treatment resulted in an $18 \%$ reduction in leaf area, which was significant at $P=0.02$ (Table 3). 


\section{DISCUSSION}

Only one previous, published study has been on the effects of lime on apple scab (15), and none has dealt with pear scab. Miller and Rich (15) reported that an autumn application of 0.17 metric tons of lime per hectare caused a reduction of 7 , 32 , and $56 \%$ in the number of ascospores discharged in April, early May, and late May, respectively, of the following year. They found that nitrogenous fertilizers (10-10-10 at 0.14 metric tons per hectare and urea at 0.03 metric tons per hectare) caused a greater reduction in ascospore discharge than lime. The effect was attributed to an increase in the bacterial population of the apple leaves (5). The most important biological agent that removes apple leaves from the orchard floor is the earthworm Lumbricicus terrestris $(16,17)$. Urea and other nitrogenous compounds increase the softening rate of leaf litter and, thus, their palatability to earthworms (4). The effect of lime on softening of leaves has not been studied, but earthworms were excluded from the leaves in our study. The amount of lime applied by Miller and Rich (15) was considerably less than that applied in our study. Our application rates were based on local extension recommendations.

Liming enhances microbial activity, resulting in more rapid decomposition of leaf litter $(6,19)$. We found that 5.08 metric tons of dolomitic lime per hectare reduced leaf area 18 and $34 \%$ for apple and pear, respectively. A study of beech leaf decomposition on German forest soils showed that decomposition was higher in lime soils than in acid soils (12). In a study done in acidic peat bogs in upland Britain, decomposition of plant litter was positively correlated with the calcium concentration of litter components (11). Lignin and tannin concentrations had a negative effect on decomposition, and a complex interaction of calcium, phosphorus, and organic molecules was described with multiple regression analysis (11). In another study, leaves of 19 tree species were inoculated with a forest humus suspension and the rate of decomposition from 2 to 6 months was most closely related to the excess base content of the litter (2). Excess base in soil neutralizes soil acidity (2).

The reductions that we observed in leaf area were considerably less than the reduction of ascospore dose that occurred following the application of dolomitic lime (55 to $92 \%$ for apple, 46 to $88 \%$ for pear). Thus, factors other than leaf decomposition must be involved. Cook (7), using phosphate buffers applied to detached scabby apple leaves, showed that the number of pseudothecia per $\mathrm{cm}^{2}$ decreased sharply as the $\mathrm{pH}$ on the leaf surface approached 7.0. Urea also may suppress pseudothecial development by raising the leaf $\mathrm{pH}$ to an alkaline level (7). Dolomitic lime undoubt- edly increases the $\mathrm{pH}$ of apple and pear leaves, but the extent of the increase has not been determined.

The number of pseudothecia per leaf in this study was quite low, even in the absence of lime. We have counted as many as 64 to 204 pseudothecia per leaf for d'Anjou and Bartlett pear, respectively ( $R$. A. Spotts, unpublished data). Infected apple leaves have a mean of 21.6 mature pseudothecia per fertile lesion, but low lesion fertility often results in pseudothecial density (mature ascocarps per visible lesion) values of less than 2.0 (9). The values reported herein (2.0 to 2.7 pseudothecia per leaf for nonlimed pear leaves and 2.5 to 3.7 for apple leaves) may be the result of several factors, including a high percentage of sterile lesions, poor leaf contact with the ground because of the underlying nylon mesh, and periodically reduced light from fallen leaves and fruit on top of the mesh (13).

If the potential ascospore dose is close to the critical threshold for a given management program, sanitation practices such as leaf shredding or application of urea can be used to further reduce the ascospore dose (14). Several management practices with mediocre individual efficiency have, collectively, the potential to greatly reduce $V$. inaequalis populations (14). This may be the usual situation in the Hood River Valley, where apple and pear scab are often not major problems in commercial or-

Table 1. Effect of dolomitic lime on Venturia pirina in pear leaves

\begin{tabular}{|c|c|c|c|c|c|c|c|c|}
\hline \multirow[b]{2}{*}{ Pseudothecial measure } & \multirow[b]{2}{*}{ Year } & \multicolumn{4}{|c|}{$\begin{array}{l}\text { Dolomitic lime } \\
\text { (metric tons/ha) }\end{array}$} & \multirow[b]{2}{*}{ Slope $^{x}$} & \multirow[b]{2}{*}{ Intercept $^{\mathrm{x}}$} & \multirow[b]{2}{*}{$r^{\mathrm{y}}$} \\
\hline & & $\mathbf{0}$ & 1.27 & 2.54 & 5.08 & & & \\
\hline \multirow[t]{2}{*}{$\overline{\text { Leaves with pseudothecia }(\%)^{\mathrm{z}}}$} & 1994 & 57.9 & 47.2 & 41.7 & 20.4 & -18.18 & 43.04 & 0.864 \\
\hline & 1995 & 63.8 & 53.4 & 49.1 & 45.0 & -10.70 & 53.55 & 0.993 \\
\hline \multirow[t]{2}{*}{ Pseudothecia per leaf $^{\mathrm{z}}$} & 1994 & 2.0 & 1.3 & 1.0 & 0.4 & -0.86 & 1.22 & 0.963 \\
\hline & 1995 & 2.7 & 1.8 & 1.7 & 1.6 & -0.65 & 2.01 & 0.981 \\
\hline \multirow[t]{2}{*}{ Asci per pseudothecium } & 1994 & 134.2 & 108.9 & 69.9 & 69.5 & -39.26 & 98.30 & 0.931 \\
\hline & 1995 & 121.9 & 98.9 & 93.9 & 92.5 & -18.05 & 103.03 & 0.990 \\
\hline
\end{tabular}

${ }^{\mathrm{x}}$ Regression of $Y$ on $\log (X+0.1)$ where $X$ is metric tons of dolomitic lime per ha.

${ }^{y}$ All coefficients are significant at $P=0.05$ except leaves with pseudothecia and asci/pseudothecium in 1994.

${ }^{z}$ Values are the means of a total of 53 to 60 leaves sampled biweekly (eight times) each year. Means of the biweekly values were used in regression analysis.

Table 3. Effect of dolomitic lime on ascospore dose of Venturia inaequalis and V. pirina and on leaf area

\begin{tabular}{|c|c|c|c|c|c|c|}
\hline \multirow{3}{*}{$\begin{array}{l}\text { Dolomitic lime } \\
\text { (metric tons/ha) }\end{array}$} & \multicolumn{4}{|c|}{ Reduction of ascospores $(\%)^{y}$} & & \\
\hline & \multicolumn{2}{|c|}{ Apple } & \multicolumn{2}{|c|}{ Pear } & \multicolumn{2}{|c|}{ Leaf area $\left(\mathrm{cm}^{2}\right)^{\mathrm{z}}$} \\
\hline & 1994 & 1995 & 1994 & 1995 & Apple & Pear \\
\hline 0.00 & $\ldots$ & . & $\ldots$ & & 107 a & 101 \\
\hline 1.27 & $\ldots$ & . . & 46 & 46 & $\ldots$ & 90 \\
\hline 2.54 & & & 70 & 51 & & 72 \\
\hline 5.08 & 92 & 55 & 88 & 54 & $88 \mathrm{~b}$ & 67 \\
\hline
\end{tabular}

y Values calculated from percent leaves with pseudothecia, pseudothecial density, and number of asci per pseudothecium.

${ }^{\mathrm{z}}$ Mean leaf area of three (apple) and four (pear) evaluations measured in 1995. Reduction of apple leaf area was significant at $P=0.02$ according to paired $t$ test. Regression of pear leaf area $(Y)$ on $\log (X+0.1)$ where $X=$ metric tons dolomitic lime $/ \mathrm{ha}=-26.4 X+76.7, r=0.95$ and is significant at $P=0.05$. chards. The 17-year average number of and usually a maximum of five fungicide applications for apple and three for pear (R. A. Spotts, (unpublished data). Under conditions of low inoculum and relareduction in ascospore dose resulting from overall management of apple and pear scab. Currently, lime application is viewed River Valley as a supplement to fungicides inaequalis in apple leaves

\begin{tabular}{|c|c|c|c|}
\hline \multirow{2}{*}{$\begin{array}{l}\text { Pseudothecial } \\
\text { measure }\end{array}$} & \multirow[b]{2}{*}{ Year } & \multicolumn{2}{|c|}{$\begin{array}{l}\text { Dolomitic lime } \\
\text { (metric tons/ha) }\end{array}$} \\
\hline & & 0 & 5.08 \\
\hline \multirow{2}{*}{$\begin{array}{l}\text { Leaves with pseu- } \\
\quad \text { dothecia }(\%)^{\mathrm{z}}\end{array}$} & 1994 & $95.2 \mathrm{a}$ & $46.9 \mathrm{~b}$ \\
\hline & 1995 & $58.2 \mathrm{a}$ & $45.5 \mathrm{~b}$ \\
\hline \multirow{2}{*}{$\begin{array}{l}\text { Pseudothecia per } \\
\text { leaf }^{z}\end{array}$} & 1994 & $3.7 \mathrm{a}$ & $0.5 \mathrm{~b}$ \\
\hline & 1995 & $2.5 \mathrm{a}$ & $1.6 \mathrm{~b}$ \\
\hline \multirow{2}{*}{$\begin{array}{l}\text { Asci per pseudothe- } \\
\text { cium }\end{array}$} & 1994 & 139.3 & 69.0 \\
\hline & 1995 & 121.4 & 86.5 \\
\hline
\end{tabular}

Numbers within rows followed by different 0.01 according to paired t test. Values are the . biweekly (seven observations in 1994, eight in 1995).
Table 2. Effect of dolomitic lime on Venturia 
in problem orchards rather than as a means to reduce the number of fungicide applications. However, lime is applied only when soil $\mathrm{pH}$ requires adjusting, about once every 4 to 5 years. Growers are cautious about omitting a fungicide application because of the high value of fresh market fruit, which makes up $74 \%$ of the Hood River pear crop and $67 \%$ of the apple crop (1). In addition, there is no economic advantage to replacing a fungicide application with a lime application intended solely for scab ascospore population reduction. Lime application costs about $\$ 145$ per hectare (2.54 metric tons), compared with $\$ 112$ per hectare for a fungicide (combination of mancozeb and triflumizole) (F. J. A. Niederholzer, unpublished data). Further commercial trials are necessary to validate the utility of lime for scab management.

\section{LITERATURE CITED}

1. Anonymous. 1995. Hood River Valley Production 1988-1994. Ann. Rep. Hood River Grower-Shipper Assoc.

2. Broadfoot, W. M., and Pierre, W. H. 1939. Forest soil studies: I. Relation of rate of decomposition of tree leaves to their acid-base balance and other chemical properties. Soil Sci. 48:329-348.

3. Burchill, R. T. 1968. Field and laboratory studies on the effect of urea on ascospore production of Venturia inaequalis (Cke.) Wint. Ann. Appl. Biol. 62:297-307.

4. Burchill, R. T., and Cook, R. T. A. 1971. The interaction of urea and micro-organisms in suppressing the development of perithecia of Venturia inaequalis (Cke.) Wint. Pages 471483 in: Ecology of Leaf Surface Microorganisms. T. F. Preece and C. H. Dickinson, eds. Academic Press, London.

5. Burchill, R. T., Hutton, J. E., Crosse, J. E., and Garrett, C. M. E. 1965. Inhibition of the perfect stage of Venturia inaequalis (Cooke) Wint. by urea. Nature 205:520-521.

6. Condron, L. M., Tiessen, H., Trasar-Cepeda, C., Moir, J. O., and Stewart, J. B. W. 1993. Effects of liming on organic matter decomposition and phosphorus extractability in an acid humic Ranker soil from Northwest Spain. Biol. Fertil. Soils 15:279-284.

7. Cook, R. T. A. 1969. Studies on the overwintering of Venturia inaequalis (Cke.) Wint. $\mathrm{Ph}$.D. diss. University of London.

8. Gadoury, D. M., and MacHardy, W. E. 1982. Preparation and interpretation of squash mounts of pseudothecia of Venturia inaequalis. Phytopathology 72:92-95.

9. Gadoury, D. M., and MacHardy, W. E. 1986. Forecasting ascospore dose of Venturia inaequalis in commercial apple orchards. Phytopathology 76:112-118.

10. Gupta, G. K. 1979. Role of on-season, post harvest and pre leaf fall sprays in the control of apple scab (Venturia inaequalis). Indian J. Mycol. Plant Pathol. 9:141-149.

11. Heal, O. W., Latter, P. M., and Howson, G. 1978. A study of the rates of decomposition of organic matter. Pages 149-150 in: Production Ecology of British Moors and Montane Grasslands. O. W. Heal, D. F. Perkins, and W. M. Brown, eds. SpringerVerlag, Berlin.

12. Herlitzius, R., and Herlitzius, H. 1977. Decomposition of leaf litter in acid and lime soil beech forests. Oecologia 30:147-171.

13. Hirst, J. M., and Stedman, O. J. 1962. The epidemiology of apple scab (Venturia inaequalis (Cke.) Wint.) II. Observations on the liberation of ascospores. Ann. Appl. Biol. 50: 525-550.

14. MacHardy, W. E. 1996. Apple scab biology, epidemiology, and management. American Phytopathological Society, St. Paul, MN.

15. Miller, P. M., and Rich, S. 1968. Reducing spring discharge of Venturia inaequalis ascospores by composting overwintering leaves. Plant Dis. Rep. 52:728-730.

16. Niklas, J., and Kennel, W. 1981. The role of the earthworm Lumbricicus terrestris (L.) in removing sources of phytopathogenic fungi in orchards. Gartenbauwissenschaft 46:138 142.

17. Raw, F. 1962. Studies of earthworm populations in orchards. I. Leaf burial in apple orchards. Ann. Appl. Biol. 50:389-404.

18. Sutton, D. K., and MacHardy, W. M. 1993. The reduction of ascosporic inoculum of Venturia inaequalis by orchard sanitation. (Abstr.) Phytopathology 83:247.

19. Wolters, V. 1989. The influence of omnivorous elaterid larvae on the microbial carbon cycle in different forest soils. Oecologia 80:405-413. 